\title{
STRATEGIC INVESTMENT INCENTIVES: TURKISH CASE
}

\author{
Canatay HACIKÖYLÜ ${ }^{1}$
}

\author{
Zeynep KARAL ÖNDER ${ }^{2}$
}

\begin{abstract}
The three main instruments of fiscal policy are tax, expenditure and debt. An example of fiscal policy in terms of expenditure is state aids, which is frequently used by an intervention of the state. State aid is a concept that includes expressions such as the incentive and support measure, which is common in daily language.The state aid is determined support given to the production of certain goods and services to a specific region, sector, business or group of enterprises by using public resources.

In Turkey, in addition to the support given in previous years, strategic investment incentives started to be implemented in 2012 with 3305 No. "Decisions About State Aid for Investment". Strategic investment incentives are a spending policy aimed at reducing the current account deficit and eliminating import dependency in the long run, which is applied to products with high import dependency.

This study aims to explore the impact of strategic investment incentive system on investments by examining the strategic investment practices regarding 3305 No. "Decisions About State Aid for Investment".66.503 incentive certificates were issued between 2012 and 2015, of which only 48 are strategic investment incentives. On the other hand, $13 \%$ (138.8 billion TL) of the total capital incentive of 1 trillion TL is strategic investmnet incentives. In this context, within the scope of strategic investment incentives(2012-2018), a survey will be carried out with 48 enterprises. The survey included effects of incentives on investors, operation and result of strategic investment incentive system, suggestions. As a result, policy implication will be presented about the applicability of the strategic investment incentive system and whether the tax advantages have reached their goal.
\end{abstract}

Keywords: The Strategic İnvestment İncentive, Current Account Deficit, Import Dependency, State Aid

JEL Code: H32 - H50

\section{Introduction}

The three main instruments of fiscal policy are tax, expenditure and debt. An example of fiscal policy in terms of spending is state-aid that often used by the government and is an important policy tool. State-aid is an umbrella term including incentives, subsidy, government support. State aid refers to the incentive given to the production of certain goods and services by using public resources to a specific region, sector, business or enterprise group.

The strategic investment was implemented an incentive system with the cabinet decision numbered 3305 namely "Decision on State-Aid on Investments" in 2012. The objective of decree's first article determine "to regulate the principles and procedures to orient savings to investments with high added value, to increase production and employment, to encourage strategic investments and regional and large scale investments which shall increase the international competitive power and which have a high research and development content, to increase international direct investments, to decrease regional development differences, to

\footnotetext{
1 Asst. Prof., Anadolu University - Faculty of Economics - Public Finance Department, chacikoylu@anadolu.edu.tr

2 Dr., Anadolu University - Faculty of Economics - Public Finance Department, zkaral@anadolu.edu.tr
} 
support investments related to environmental protection and clustering and to support research and development activities related with such investments in conformity with the objectives of development plans and annual programs."

In 2012 with the investment incentives decision set also goal about current account deficit which is an economic problem for Turkey. In this context, $8^{\text {th }}$ article of decree states that "investments of products with a high dependency on imports will be supported under strategic investments". Investments that supported in this context are not predetermined by the policymaker. Each sector can benefit from strategic investment incentive if meets criteria. These criteria are:

- The domestic production capacity for the product to be manufactured with the investment shall be less than the import of the product.

- The investment shall have a minimum investment amount of TRY 50 million.

- The investment shall create a minimum added-value of $40 \%$ (this condition is not applicable to refinery and petrochemicals investments).

- The total import value of the product to be manufactured with the investment shall be minimum of USD 50 million as of the past one year (excluding products that are not locally produced) (Sanayi ve Teknoloji Bakanlığı, 2019: 37).

The terms and rates of support provided within the Strategic Investment Incentives Scheme are VAT Exemption, Customs Duty Exemption, Tax Reduction, Social Security Premium Support (Employer's Share), Land Allocation, VAT Refund, Social Security Premium Support (Employee's Share) (for investments in Region 6), Income Tax Withholding Allowance (for investments in Region 6) (Sanayi ve Teknoloji Bakanlığı, 2019: 38) .

\section{Turkish Economy and Current Account Deficit}

Balance of Payments is a statistical report prepared to show the systematic records of economic transactions between residents of a country with residents of another country (non-residents) over a certain period of time. The current account includes the trade goods and services and primary and secondary income accounts in the balance of payments. In the current account, when the debt exceed the income, in other words, when the difference is negative the result is called a current account deficit (TCMB, 2019).

The ratio of current account deficit to GDP for developing countries is an important indicator for all economic actors. The ratio of current account deficit to GDP range \%-9 and \%-3,7 between 2010-2018 in Turkey. Despite the fact that the ratio of the current account deficit to the GDP ratio is not always an indicator of destabilization in the literature, there are many studies that sustainability of current account deficit is \% 4-5 (Babaoğlu, 2005: 10-11).

Current account deficit studies and discussions for Turkey started after "24 January Decision" in 1980. The result of the neo-liberal policies of the 1980 s, with the liberalization of foreign trade, total production was directed to exports, imports increased by $56 \%$ compared to the previous year and current account deficit increased by 2.8 times. The reason for this increase is the fact that exports are based on production with imported intermediate goods. After 1989, the foreign trade balance acquired a new dimension with the removal of all barriers to capital movements. The source of demand expansion was not individual demand expansion but uncontrolled capital inflows. The result of uncontrolled capital inflows occurs demand expansion and rising 
current account deficit (Boratav, 2005: 145-192). After 2002, current account deficit increased as a result of the rapid increase in imports, this deficit was financed by hot money inflows and foreign direct investment incentives (Boratav, 2010: 455).

Figure 1 shows the components of imports between 1996-2018 according to Classification of Broad Economic Categories (BEC). In the last 22 years, Turkey's \%70 average imports are intermediate goods. With the simple analysis, this figure shows that industrial production in Turkey is foreign-dependent. In this case, Turkey's production depends on the uncertainty in world input sources, the dynamics of the source country and the fluctuations in product prices. In addition, the added value created by the production within the country has to be shared with the foreign markets because of imports. One of the most important problems of the use of imported intermediate goods is the negative impact on competitiveness for following an export-oriented growth strategy (Ekonomi Bakanlığı, 2012).

Figure 1: The Components of Imports according to BEC

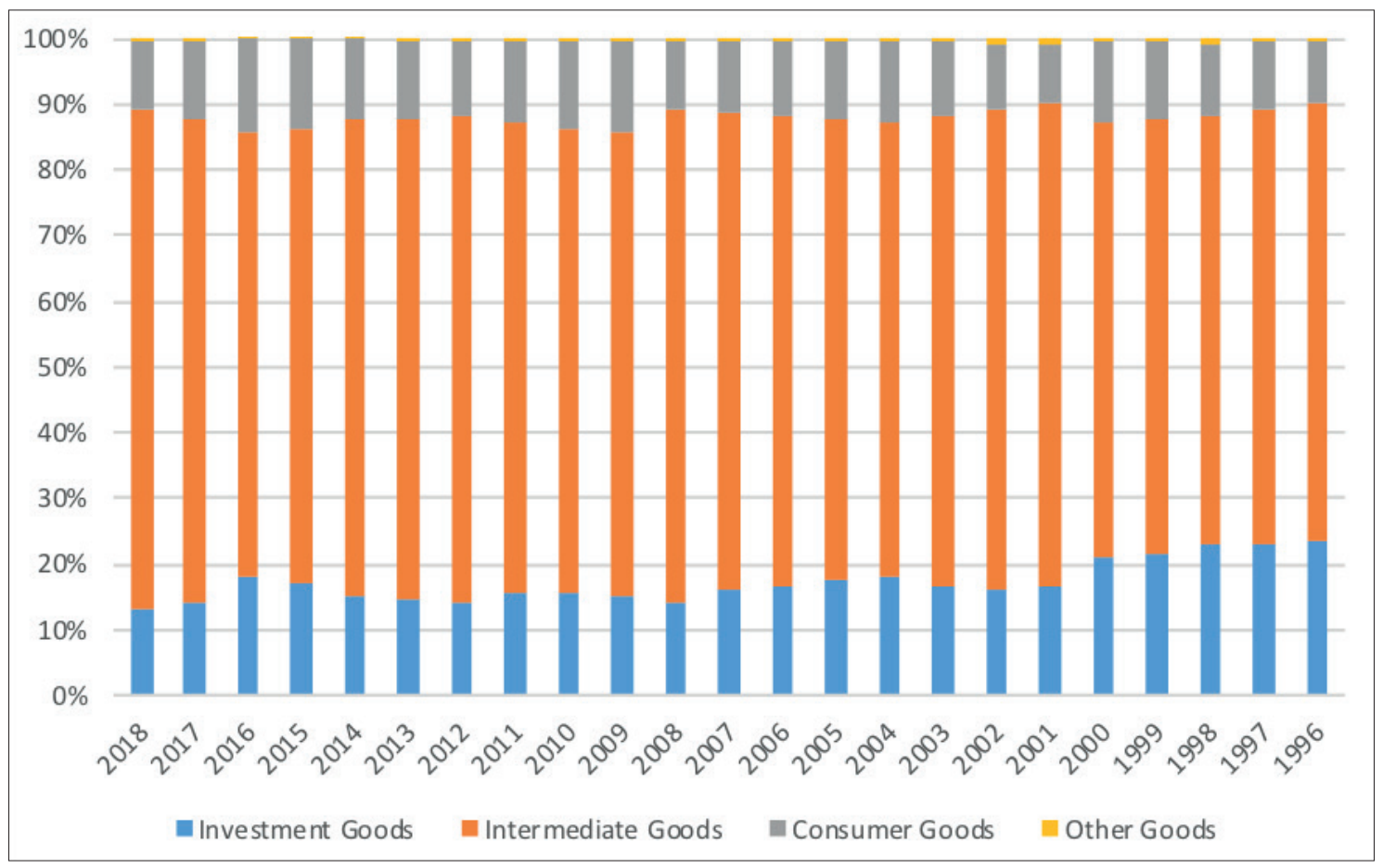

Source: TUIK, 2019

As a result, from the 1980 s to the present, the short history of the current account deficit shows that the export-oriented growth strategy brings with high imports (especially imports of intermediate goods) and result in current account deficit.

\section{The Relation between Strategic Investment and the Current Account Deficit}

Strategic investment incentives are presented as a policy for the current account deficit (Ekonomi Bakanlğı, 2012). These policies aim to reduce the import of treated raw materials for industry and to promote investments in these areas in Turkey. We can define this policy as localization (YASED, 2011, s. 13). Strategic investment incentive is based on supporting high value-added investments that will contribute to the reduction of the current account deficit. 
The strategic investment incentive policy has been determined for the sectors that use imported intermediate goods and raw materials. These sectors are the source of high foreign trade deficit. These sectors are defined by the "Input Supply Strategy(ISS)" that prepared by the Ministry of Economy and published in the Official Gazette as of December 2012. The aim of ISS is to direct both domestic and foreign investment expenditures to these sectors. Unprocessed high raw material importing sectors are determined as iron-steel, mining, automotive and machinery, chemical products, textile and agriculture (T.C. Ekonomi Bakanlığı, 2012, s. 17-23). The sectors have not changed in the Input Supply Strategy Action Plan for the years 2017-2019. In this context, the strategic investment incentives aim to reduce imports of raw materials and to promote investment in this sector to reduce the current account deficit in Turkey.

\section{Strategic Investment Incentive Practices}

48 investment was provided incentive within the scope of strategic investment incentives between 2012-2018. With the incentive system, a total of TL 1 trillion of incentives was provided, of which TL 138.8 million, or 13\%, was provided as a strategic investment incentive. 38 of these investments made by domestic capital and 10 by foreign capital. On the other hand, $60 \%$ amount of the total strategic investments were made by foreign capital. According to the investment capital, $87 \%$ of the investments is a greenfield investment, $9 \%$ expansion and $4 \%$ other (product diversification). When we examine the sector, the most investment incentive certificate is given to the manufacturing sector with $61 \%$, while the sector with the most capital is the energy sector with $60 \%$. When we examine the sub-sectors, the energy sector is followed by the chemical and extraction and processing (mine) sectors in terms of the fixed investment amount.

When the strategic investments incentives and sectors prioritized by ISS are examined, the investments are made in the sectors of mining and chemical products, while investor in the iron and steel, automotive and machinery, textile and agriculture sectors didn't receive or demand incentives. Although the expectations for strategic investment incentive policy were very high, this expectation has not been met yet. In this context, 48 strategic investors will be interviewed and their opinions will be compiled by a questionnaire. Thus, in terms of strategic investment incentives practices of investors will put forward and positive and negative aspects of topic will be evaluated in the context of Turkey. At this stage, it will be tried to explain whether the tax advantages have been achieved in strategic investment incentives.

\section{References}

Babaoğlu, B. (2005). Türkiye'de Cari işlemler Dengesi Sürdürülebililiği, D. S. Böke, Ed., (Yüksek Lisans Tezi), Ankara.

Boratav, K. (2005). Türkiye Iktisat Tarihi 1908-2002, Ankara, İmge Kitabevi.

Boratav, K. (2010). Emperyalizm, Sosyalizm ve Türkiye, İstanbul, Yordam Kitap.

Ekonomi Bakanlığı. (2012). Girdi Tedarik Stratejisi (GiTES) ve Eylem Planı, Ankara, Ekonomi Bakanlığı.

Ekonomi Bakanlığı. (2012). Yeni Teşvik Sistemi-Yatırımlarda Devlet Yardımları, İstanbul, T.C. Ekonomi Bakanlığı-Teşvik Uygulama ve Yabancı Sermaye Genel Müdürlüğü, Nisan 06. 
Sanayi ve Teknoloji Bakanlığı. (2019). Yatırım Teşvik Sistemi-Yatırımlarda Devlet Yardımları. Ankara, Sanayi ve Teknoloji Bakanlığı.

Ekonomi Bakanlığı. (2012). Girdi Tedarik Stratejisi ve Eylem Planı (2013-2015), Ankara, T.C. Ekonomi Bakanlığı.

TCMB. (2019). Ödemeler Dengesi Istatistikleri-Metaveri, Retrieved from Ödemeler Dengesi İstatistikleri: https://www.tcmb.gov.tr/wps/wcm/connect/TR/TCMB+TR/Main+Menu /Istatistikler/Odemeler+Dengesi+ve+IIgili+Istatistikler/Odemeler+Dengesi+Istatistikleri/.

TUiK. (2019). Dış Ticaret Istatistikleri, Retrieved from Türkiye İstatistik Kurumu: http://www. tuik.gov.tr/PreTablo.do?alt_id=1046, Şubat 20.

YASED. (2011). Türkiye'nin Cari Açığı: Makro ve Mikro Açıdan Nedenleri ve Çözüm Önerileri, İstanbul, YASED. 